\title{
Treaty: advancing reconciliation?
}

\author{
The Hon David Malcolm AC
}

\section{Introduction}

Just before the end of his term as Governor-General, Sir William Deane, in an address to the University of New South Wales said:

[in] the forefront of those challenges [that still lie ahead for Australians] are the challenge to heal the divisions in our society including the unacceptable gap between the haves and the have-nots; the challenge to protect and preserve our environment for future, as well as present, Australians; the challenge to overcome entrenched Aboriginal disadvantage and to achieve true and lasting Aboriginal reconciliation.

He continued:

In that regard, my abiding regret as my term as Governor-General expires is that we Australians failed to achieve more before the life of the Council for Aboriginal Reconciliation ran out at the end of last year.

In the search for Aboriginal reconciliation, our Universities have an absolutely critical direct and indirect role to play. The direct role includes the obvious one of encouraging and effectively teaching those Indigenous Australians who are fortunate enough to come within their reach. I say 'fortunate enough' because of the immense gap which continues to exist in many areas of our nation between the educational standards, including literacy and numeracy, of the average Indigenous student leaving school and the average non-Indigenous one. While the position varies in different areas and while there is room for informed disagreement about some details, a number of plain facts are beyond intelligent dispute. For me the most basic of them is that in many remote Indigenous communities, there is, for practical purposes, no chance that an Indigenous student will reach matriculation standard. Indeed, in some of those communities, the standard of the average Aboriginal student at the conclusion of formal education is Year Three (3) primary school. Obviously, in the context of the past treatment of our Indigenous peoples, our Universities have an immense responsibility to ensure that, consistently with the 
maintenance of academic standards, every legitimate encouragement and assistance is extended to the Indigenous students who succeed in entering their doors. ${ }^{1}$

It is an honour to have been invited by Murdoch University to be a Keynote Speaker at this national Conference on racism, land and reconciliation. In the year 2000, when we celebrated the Centenary of our Federation, I was honoured to join the delegation from Western Australia which attended the Corroboree 2000 Reconciliation Conference in Sydney, and later to participate as a leader in the Australians for Reconciliation 'Beyond the Bridge' Walk here in Western Australia in 2001 which culminated with speeches and entertainment in the Supreme Court Gardens. Since 1993, the Judges of the Supreme Court have been pursuing the reconciliation agenda through various Aboriginal cross-cultural awareness programmes and through reaching out in an endeavour to communicate with Aboriginal communities throughout the State when on circuit or otherwise. I have been privileged to have been involved in informal discussions with various Aboriginal leaders and others on the ways and means of bringing together the various disparate groups of Aboriginal people in the Perth metropolitan area in an attempt to develop a united approach, both to reconcile the various factional groups among the Nyungah and others in the area among themselves, as well as to reconcile relationships between the metropolitan Aboriginal peoples, on the one hand, and the remainder of the community on the other.

This paper explores first, the idea or concept of a treaty or series of treaties between Indigenous and non-Indigenous Australians as a step towards reconciling these cultures within the framework of the Australian nation, and second, questions regarding the use of a treaty within the constitutional framework of Australia.

\section{The idea of a treaty and its implementation in Australia}

The idea of a treaty between the Indigenous and non-Indigenous peoples of Australia is not new. In 1837 the first Attorney General of New South Wales, Saxe Bannister, made a submission for a treaty to the Select Committee of the House of Commons on Aborigines. ${ }^{2}$ The retired Governor Arthur of Tasmania also urged this Committee to consider treaties. In 1835 a treaty negotiated by John Batman with the Kulin people was declared invalid by the Governor of Victoria as it was made by a private citizen. ${ }^{3}$ In 1975 the Senate passed a resolution put by Senator Bonner urging the Australian Government to acknowledge the prior ownership of Australia by Indigenous peoples and to introduce legislation to compensate them for dispossession of their land.

In 1979 the Aboriginal Treaty Committee, under the chairmanship of Dr HC Coombs, was established with the 'aim of influencing and mobilising non-Aboriginal opinion in favour of the treaty and of granting land rights and compensation'. ${ }^{4}$ This was disbanded in 1983. The Committee's newspaper, Aboriginal Treaty News, March-June 1983 edition reported that the Committee was disbanded because its work in influencing non-Aboriginal attitudes had been significant, political parties now gave greater weight to Aboriginal issues, and the Committee had mobilised greater support for independent Aboriginal initiatives.

The idea of a treaty was rejected in 1983 by the Senate Standing Committee on Constitutional and Legal Affairs. The Committee considered that the Indigenous peoples were not a sovereign

${ }^{1}$ Deane 2001. $\quad{ }^{2}$ CAR 2000. $\quad{ }^{3}$ CAR 2000. $\quad{ }^{4}$ See Australian Institute of Aboriginal and Torres Strait Islander Studies. 
entity and therefore could not enter into a treaty with the Commonwealth, although they supported a compact which could be inserted into the Constitution by referendum. ${ }^{5}$ In the lead-up to the bicentennial celebrations in 1998, the issue of a negotiated treaty was raised again by the then Prime Minister Bob Hawke. ${ }^{6}$ A statement of Indigenous aspirations was presented to Mr Hawke at the Barunga Festival in June 1988. The Barunga statement called on the Commonwealth Government to negotiate a treaty recognising Indigenous peoples' prior ownership, continued occupation, sovereignty and rights in a range of areas. ${ }^{7}$

The Prime Minister responded by calling for a treaty to be negotiated between the Indigenous people of Australia and the Government. ${ }^{8}$ The concept of an instrument or document of reconciliation was put forward as a formal step in the reconciliation process in a discussion paper released by the Australian Government through the then Minister for Aboriginal Affairs, the Hon Mr Robert Tickner, in February 1991. ${ }^{9}$ Mr Tickner said the discussion paper proposed a strategy 'for achieving reconciliation and social justice for Aboriginal and Torres Strait Islander people'. The discussion paper stated:

[T]he Government's position is that the document which could be called an instrument of reconciliation would be a valuable outcome of the process of reconciliation and such a document should desirably be achieved by the centenary of Federation, 1 January 2001.

However, the process of reconciliation may be as important as the final outcome and the initial focus would be on the process rather than on the document. The best possible outcome is one reflecting a consensus arrived at through extensive community discussion. ${ }^{10}$

While support for an instrument of reconciliation was not unanimous, there was continued support for reconciliation, leading to the establishment of the Council for Aboriginal Reconciliation in September $1991 .{ }^{11}$ The Council was given a statutory requirement to seek community views about whether any document or documents of reconciliation would benefit the Australian community. ${ }^{12}$

Since the publication of that discussion paper, the centenary of Federation as the desired date indicated by the former Government for the completion of such a document has passed. The process of reconciliation must be kept alive by the discussion of the issues that are relevant to any proposed document of reconciliation. With the year of the centenary of Federation over and the mandate of the Council for Aboriginal Reconciliation expired, reconciliation has been seen by some as a people's movement. ${ }^{13}$ It has been suggested that the difficulty with this approach is that such support often wanes when it comes to specifics such as the recognition of distinct rights, return of lands, self-government and compensation. ${ }^{14}$ There has been a call for greater political leadership, as it is the government that has the resources, authority and power to achieve reconciliation. ${ }^{15}$

The present Government has rejected the proposal for a treaty with Indigenous people and has coined the phrase 'practical reconciliation' to describe its policy focus. ${ }^{16}$ This involves an emphasis on dealing with social problems and the provision of the resources by the government

$\begin{array}{llll}{ }^{6} \text { CAR 2000. } & { }^{8} \text { CAR 2000. } & { }^{11} \text { CAR 2002. } & { }^{14} \text { Strelein 2000: } 260 . \\ { }^{7} \text { See Indigenous Law } & { }^{9} \text { Cockayne 2001: 590. } & { }^{12} \text { Cockayne 2001: 590. } & { }^{15} \text { Strelein 2000: } 260 . \\ \text { Resources 1994. } & { }^{10} \text { Tickner 1991. } & { }^{13} \text { Cockayne 2001: 577. } & { }^{16} \text { Oxfam 2000. }\end{array}$


to deliver basic services to Indigenous communities. The argument against this policy has been that it will assimilate Indigenous Australians into mainstream society. ${ }^{17}$ It is also argued that the implementation of the policy will remove the decisions as to how and when the services are provided away from the Indigenous people.

Although a fundamental part of the 'unfinished business' agenda, the claims made by the Indigenous people of Australia are not limited to the equal distribution of resources and the enjoyment of fundamental services. ${ }^{18}$ The collective enjoyment of distinct cultural rights and collective rights is also claimed and emphasis is placed on a contention that the divide that exists in relation to the equal enjoyment of fundamental citizenship rights reflects the much deeper issue of the identity of Indigenous peoples. ${ }^{19}$ In this context, Mr Geoff Clark has argued:

... let me put it this way, if all of the endemic social and economic problems were fixed in our communities tomorrow we would still need to address our fundamental human rights. The achievement of full 'practical' reconciliation, as the Government describes, would be just one step along the road to true reconciliation. ${ }^{20}$

One of the difficulties in commenting on a topic dealing with Indigenous people is the inadequacy of the English language and European culture to speak accurately or authoritatively about the culture and experience of Australian Indigenous peoples. This is true wherever a colonial power has encountered an Indigenous people, because as was said about the Navajo Indians in 1946:

... each different way of life makes its own assumptions about the ends and purposes of human existence, about ways by which knowledge may be obtained, about the organization of the pigeon-holes in which each sense datum is filed, about what human beings have a right to expect from each other and the gods, about [what] constitutes fulfilment and frustration. Some of these assumptions are made explicit in the lore of the folk; others are tacit premises which the observer must infer by finding consistent trends in word and deed. ${ }^{21}$

In my view, the same principles apply to the clash of cultures which commenced a little over 200 years ago when white people first settled in the Great South Land that came to be called Australia. It continues to this day. It is still the principal issue in Indigenous-non-Indigenous relationships, notwithstanding the significant changes in perception that have occurred over the past three decades.

At the time of European colonisation in 1788 the Aboriginal population was estimated to be between approximately 300,000 and 1,500,000 persons. The 2001 Census statistics indicate that the Indigenous population of 410,003 people represents $2.2 \%$ of the Australia population. ${ }^{22}$ There were perhaps 500 tribes in 1788 , and as many dialects and languages, whose people lived in scattered groups throughout the Australian continent. In their World of the First Australians $^{23}$ Professor and Doctor Berndt undertook a comprehensive survey of traditional Aboriginal culture. It is clear from their work that the complexity of the Aboriginal society was

\footnotetext{
${ }^{17}$ Australians for Native Title and Reconciliation 2002

${ }^{19}$ Strelein 2000: 261.

${ }^{20}$ Clark 2000.

${ }^{21}$ Kluckholm cited by Supreme Court of Alberta 1991: 9-10.

${ }^{22}$ Australian Bureau of Statistics 2002

${ }^{18}$ Strelein 2000: 261.

${ }^{23}$ Berndt and Berndt 1999 [1964].
} 
not recognised by Europeans at the time of first colonisation in 1788. Many Australians still have difficulty accepting it now.

The Aboriginal system of law prior to British colonisation was reviewed in the 1971 case of Miliipum $v$ Nabalco Pty Ltd. ${ }^{24}$ Miliipum involved a claim by a group of Aboriginal people in the Northern Territory, citing the authority of the common law, to a proprietary interest in certain land. They were unsuccessful. Justice Blackburn said of the Aboriginal system of law in the Northern Territory at the time of colonisation that:

... it shows a subtle and elaborate system highly adapted to the country in which the people led their lives, which provided a stable order of society and was remarkably free from the vagaries of personal whim or influence. If ever a system could be called 'a Government of laws' and not of men it is that shown in the evidence before me. ${ }^{25}$

The need for a process of reconciliation between Aboriginal and non-Aboriginal persons has been recognised for many years. The first real step in this reconciliation process was the socalled 'Aboriginal Referendum' of 1967 in which the then Federal Coalition Government and the Labor Opposition joined to give a unanimous commitment to constitutional change to effectively give Aboriginal people full citizenship. The Australian people responded to that clear and powerful message - and a record $92 \%$ of the Australian population supported the referendum proposing the change.

Since that time there has been an evolution of thought on the part of non-Aboriginal people that has been reflected in the actions of successive Commonwealth governments irrespective of party composition. The process of reconciliation has never been far from the political agenda. Each new report which detailed Indigenous disadvantage, each new programme which failed to achieve its objectives, each new incident which highlighted the divisions between Indigenous and non-Indigenous people and the mounting signs of Indigenous anger and frustration with the pace and direction of reform, has served to remind us that the process of reconciliation had to take place.

In developing a formal document of reconciliation, there are many issues to be taken into consideration including: what form it might take; how it could be developed; what rights might flow from it; who might negotiate it, and in particular, who might be party to it. Other issues for community consideration may be whether such a document or documents should be legally binding, and whether such a document should reflect or go beyond the developments in international law relevant to Indigenous people.

In addition to a national document of reconciliation the nation needs documents of recognition and agreement between Indigenous communities and various sectors of the wider community, for example, at local government level and between Indigenous communities and industry representatives such as mining and pastoral organisations. Already there are some positive examples of such agreements and documents that show it can be done when people from all sides are committed to making it happen.

On 17 July 2001, Nyungah Elders and Alan Carpenter, Minister for Education, signed an historic agreement at Swanbourne, one of the Western suburbs of Perth. ${ }^{26}$ The Agreement

\footnotetext{
24 (1971) 17 FLR 141. $\quad 25$ 17 FLR 141 at $267 . \quad{ }^{26}$ Nyungah Circle of Elders 2001.
} 
marked the culmination of nearly three years of negotiations between 18 Nyungah Elders and the Education Department. The Agreement relates to an important Aboriginal Site in the area of Lake Claremont (formerly known as Butler's Swamp) and the relocation of the Swanbourne Primary School at the old Swanbourne Homegrounds land, where Swanbourne High School had been located. The Site is of great significance to Nyungah people, being home to Nyungah people for generations and various Nyungah Elders, alive today, during the 1930s and 1940s. In recognition of the importance of the Site and the use of part of the land for educational purposes, the Agreement provides for the implementation of a pilot programme relating to the teaching of Nyungah history to children.

As of 29 May 2002, there were 41 determinations of native title across Australia. In addition, 48 Indigenous land use agreements have been registered and about 2,700 agreements have been made between developers and native title parties relating to future development activities. ${ }^{27}$ Of course, no document of itself will solve the many problems which lie in the path of reconciliation. However, I believe that without a document that expresses some clear commitment to reconciliation the nation and our national identity will remain incomplete. At a 1997 Workshop held by the Australians for Aboriginal Reconciliation in association with the Supreme Court of Western Australia and the Law Society of Western Australia, Patrick Dodson said that without a formal document of reconciliation, '[ $t$ ] he wounds of our nation's past will remain unhealed and will continue to fester and poison the body politic'. ${ }^{28}$

Negotiated agreements between parties at local and regional levels are one of the effective responses of the High Court Mabo judgment. Such agreements can avoid the complexities and, no doubt, the cost and length of time that occupy the courts and the court battles that take place. The achievement of negotiated agreements is a better way of resolving the complex and difficult issues involved. While the local agreements entered into by some of our cities, local government authorities and Aboriginal people are, in most cases symbolic in nature, they have recognised both the groups' continuing rights and interests and acknowledged the ongoing contribution that both groups make to the life and development of the relevant city or local government area.

The question of a national document of reconciliation throws up many challenges to us as a nation and raises the question of what it is we want to achieve. The use of the word 'treaty' to describe such a document has created quite a deal of controversy in Australia. ${ }^{29}$ The central issue the treaty proposal seeks to address is the question of the ongoing relationship between Indigenous and non-Indigenous Australians. ${ }^{30}$ The term 'treaty' immediately suggests a particular type of legal relationship, based on agreement between two sovereign entities, which many people find disturbing. ${ }^{31}$ At best the use of the term is seen by some as a misnomer for what has been described as:

... an umbrella document providing direction and perspective to all areas of policy, including land rights, self-management, customary laws and recognition of Aboriginal culture and religion ... a national declaration of shared principles and common commitments. ${ }^{32}$

\footnotetext{
${ }^{27}$ Ruddock 2002. $\quad{ }^{29}$ Fraser $2000 . \quad 31$ Cockayne 2001: 590.

${ }^{28}$ P Dodson 1997. $\quad{ }^{30}$ Cockayne 2001: 590. $\quad 32$ Hawke 1988: 7.
} 
At worst, it is seen by others as a deliberate 'recipe for separatism' and used to suggest that within Australia there are the seeds of a separate nation state, ${ }^{33}$ or 'about nothing more than compensation and power'. ${ }^{34}$

One of the central concepts of Indigenous difference is that of sovereignty. The justification for there being no treaties in place between the British Crown and Australia's Indigenous peoples is that there was no sovereign in Australia. ${ }^{35}$ It remains arguable, however, that under both international and British law of the time, Indigenous Australians possessed the characteristics of sovereignty: ownership of a defined territory, a distinct, permanent population, the capacity for international relations and identifiable forms of government. ${ }^{36}$

This does not mean that Indigenous sovereignty continues to exist and Australian courts have consistently ruled that the process of colonisation was effected by non-justiciable 'acts of state', rendering the question of the continuing existence of Indigenous sovereignty unanswerable. ${ }^{37}$ This non-justiciability of Indigenous sovereignty creates a space for a negotiated, political settlement that is fundamental to the larger achievement of reconciliation..$^{38}$ It has also been argued that the possibility of original Indigenous sovereignty has important contemporary ramifications. A United Nations Special Rapporteur suggests that without consent of the Indigenous people, any deprivation of original Indigenous sovereignty is unlawful. ${ }^{39}$ If this is correct, a negotiated settlement will provide a forum for the seeking and giving of Indigenous consent to exist within the sovereignty of the Commonwealth of Australia. It has also been suggested that in 1788 the Indigenous people may have exercised an overall 'de facto authority' over the lands they respectively inhabited. By invoking this authority and acting through leaders, their descendants could negotiate a series of agreements with the Commonwealth. ${ }^{40}$

The argument that Aboriginal sovereignty persists is based on the theory that sovereign rights, self-determination rights or self-government do not emerge from the state but are inherent in Indigenous peoples' authority and collective identity ${ }^{41}$ However, to be enforceable within the colonial structure in the absence of international recognition, these rights depend upon judicial acknowledgement by the state. ${ }^{42}$ In Australia we have a history of implicit recognition of the status of Indigenous peoples as self-governing with a unique relationship to the state through land rights legislation and statutory authorities dedicated to self-management, but the extent of this recognition is a reflection of the relationship between Indigenous peoples and the colonising state. ${ }^{43}$

Although treaties have proved to be an effective legal form for documenting the outcome of negotiations, they are not a cure-all. ${ }^{44}$ Resources must be made available for Indigenous groups to negotiate and prepare amongst themselves common negotiating positions so that they can determine the role of the treaty in the context of their own laws..$^{45}$ The plurality of Indigenous voices must be accommodated with room made for Indigenous dispute resolution techniques. Once a common position is reached, then Indigenous groups could enter into negotiations with the relevant parties. ${ }^{46}$ Also, terms such as 'self-determination' and 'self-government' create in some people's minds the possibility of separate states and governments. As evidenced by the Canadian experience, it is not the case that coming to terms with the problems of the Indigenous people necessarily divides or fragments a nation. ${ }^{47}$

\footnotetext{
33 Cockayne 2001: $591 . \quad{ }^{36}$ Cockayne 2001: 592.

34 Strelein 2000: $264 \quad 37$ Cockayne 2001: 592.

39 United Nations 1999. See also Cockayne 1002: 592.

35 Cockayne 2001: 591.

${ }^{38}$ Cockayne 2001: 592.

40 Lane 1999: 122.

41 Lane 1999: 122

42 Lane 1999: 122.

43 Strelein 2000: 262.

44 Cockayne 2001: 593.

45 Cockayne 2001: 593-4.

${ }^{46}$ Cockayne 2001: 593-4.

47 Strelein 2000: 260.
} 
The term 'agreement' has slightly different connotations than the use of 'treaty'. In his 2000 Vincent Lingiari Memorial Lecture, former Prime Minister Malcolm Fraser noted that when the word 'treaty' was used in Australia, the immediate reaction of politicians, journalists, commentators and editors indicated that they were disturbed by the use of the word. ${ }^{48}$ Mr Fraser argued that, perhaps, in Australia we should simply use the term 'agreement'. ${ }^{4}$ The other side of the argument is that we should be honest about what is being sought without concern for those who may be nervous about popular support. ${ }^{50}$ The law and mechanisms for the making of agreements are already available given the number of agreements that are already in place throughout Australia. The first agreements made under the provisions of the Aboriginal Land Rights Act in the Northern Territory were signed more than 20 years ago in $1979 .{ }^{51}$ Since then there have been agreements signed between Australian Indigenous people and resource extraction companies, railway, pipeline and other major infrastructure project companies, local and state governments, farming and grazing bodies and universities. Some are registered under the terms of the Native Title Act ${ }^{52}$ others are simple contractual agreements. ${ }^{53}$

Non-Indigenous Australians may not realise that the majority of us are in charge of our own lives in ways that many Indigenous Australians are not. ${ }^{54}$ Life expectancy and health are a good indication of this point. Important factors in the improvement of the life expectancy of the Maori people of New Zealand include Maori control of health services and health service provision in a wide context of language and development education designed to close the training gap between Maoris and non-Maoris. ${ }^{55}$ This is what 'self-determination' should be seen as meaning to Indigenous people - being able to take charge of one's own life. Selfgovernment does not have to mean the establishment of a separate sovereignty and dividing the country. For example, it can apply to running schools and local community health centres.

The Canadian experience demonstrates the success of local level agreements between Indigenous and non-Indigenous peoples. ${ }^{56}$ However, there are some issues such as constitutional recognition that must, and can only be addressed at a national level. The diversity of the Indigenous peoples of Australia necessitates that national, regional and localised responses will be needed to reconcile the sovereignty of the Crown with Indigenous peoples' rights and status. The need for differentiated outcomes has been recognised in the native title process. State framework agreements are being negotiated that reflect the engagement between Indigenous peoples and governments. A national treaty could create a framework that would allow negotiations based on the recognition of rights, negotiated opinions and limitations. ${ }^{57}$ It would allow Indigenous peoples to address issues as a collective, self-governing and sovereign interest, rather than as a corporate interest. ${ }^{58}$

The importance of treaties between States and Indigenous peoples has been recognised by the United Nations, which in 1989 appointed a Special Rapporteur on treaties, agreements and other constructive arrangements between States and Indigenous peoples. ${ }^{59}$ While there is no simple or uniform answer to the question of rights for Indigenous people in Australia, there is a wealth of experience from other countries such as the US, Canada and New Zealand.

Of the nations that previously relied upon the common law to protect human rights, Australia stands out as the only one that continues to put faith in this method of protection.

$\begin{array}{llll}{ }^{48} \text { Fraser 2000. } & { }^{51} \text { Langton 2002. } & { }^{54} \text { CAR 2002. } & { }^{57} \text { Strelein 2000: } 26 . \\ { }^{49} \text { Fraser 2000. } & { }^{52} \text { Native Title Act 1993 (Cth). } & { }^{55} \text { CAR 2002. } & { }^{58} \text { Strelein 2000: } 26 . \\ { }^{50} \text { Strelein 2001: 260. } & { }^{53} \text { Langton 2002. } & { }^{56} \text { Strelein 2000: 26. } & { }^{59} \text { Oxfam 2000. }\end{array}$


The US, Canada, South Africa, India, Pakistan, and New Zealand have all adopted a Bill of Rights, whether in statutory form or constitutionally entrenched. Even more importantly, in recognition of its accession to the European Convention on Human Rights, the United Kingdom enacted a Bill of Rights in 1998 as part of its domestic law.

The omission of a Bill of Rights from the Australian Constitution is one of the elements which marks it as different from the United States Constitution, from which a number of other provisions were derived. The omission was not by accident. The inclusion of a Bill of Rights was proposed and debated at the Conventions, which preceded and informed the drafting of the Australian Constitution. Its inclusion was defeated, somewhat ironically, on the basis that a 'due process' provision would undermine some of the racially discriminatory colonial laws in place at that time, including those that were concerned with immigration and others which were to the detriment of racial minorities. It appears that the founders were careful to ensure that the provisions of these laws would not be open to challenge on the basis of individual rights or constitutionally entrenched provisions such as a provision for due process.

The centenary of Federation stimulated public debate on the subject of the need for fundamental reforms to the Australian system of government. The various popular Constitutional Conventions organised by the non-partisan Constitutional Centenary Foundation, commemorating the constitutional conventions of the 1890s, commencing with the Sydney Convention of 1891, each tended to identify support for the inclusion of recognition of fundamental human rights in the Constitution, as well as a preamble recognising the prior occupation and special position in Australia of its Indigenous peoples. Similar sentiments came out of the various Schools Constitutional Conventions organised under the auspices of the Constitutional Centenary Foundation. In the end, however, the political and constitutional debate in the period leading up to the centenary was dominated by the republic issue and debate about the preamble. These issues also dominated the official Constitutional Convention sponsored by the Commonwealth, culminating in our latest Constitutional Referendum in 1999. That, of course, dealt with the question of whether we should become a republic and the proposals relating to the Preamble to the Constitution. The Bill of Rights debate seems to have disappeared in the wake of these other issues. Although the constitutional change required to implement a republic could have been an opportune time for incorporating a Bill of Rights, the fact that the republic issue has faded, at least for the time being, does not mean that the crucial issue of protection of human rights should also be put aside.

Central to any process of a treaty or an agreement between Indigenous peoples and the State must be the achievement of reconciliation between the different Indigenous groups so that they can join together in an instrument of reconciliation as a national level united group for the purposes of negotiation. An acceptable process of reconciliation must be found for Indigenous groups with the objective of respecting differences, but joining together as one. Many Indigenous groups have been fighting one another over the disappointments of the last decade or have found their resources consumed by administrative needs. ${ }^{60}$ Tensions exist in many parts of Australia between those Indigenous people who can demonstrate that their ancestors lived in the area and those who have arrived in the area more recently. Much of this conflict has clear historical origins in European settlement and is a by-product of the dispossession and forced relocation of Indigenous peoples. ${ }^{61}$ There may be little prospect of success in carrying out

\footnotetext{
${ }^{60}$ Hagen 2001. $\quad \quad \quad{ }^{61}$ Hagen 2001.
} 
negotiations when different groups of Indigenous people are speaking with different voices and seeking different things. ${ }^{62}$ Conflicting perspectives amongst the Indigenous people must be heard and dealt with so that leaders can emerge who have the support of all Indigenous people and are willing and able to take on the challenges of pulling together communities.

\title{
Conclusion
}

Australia's lack of progress in reconciliation weakens our capacity to offer credible criticism of the human rights record of other countries. The aspirations of the Aboriginal peoples do need to be recognised. The Aboriginal people themselves likewise need to recognise the current position and aspirations of others, including pastoralists and miners. There is a role for governments here to reconcile the aspirations and interests of all parties. In his first Ministerial Statement to the Northern Territory Parliament, Minister John Ah Kit MLA said:

\begin{abstract}
Aboriginal people in the territory must escape from the cargo cult mentality of the government doing everything for them; of relying on the empty rhetoric of playing the victim. Aboriginal organisations must bite the bullet and develop new, innovative strategies to overcome the cancerous ideologies of despair.

The other side of that coin is that the government - in partnership with the Aboriginal people - must allow the development of forms of governance that allow Aboriginal people the power to control their lives and communities. ${ }^{63}$
\end{abstract}

The opportunity for reconciliation will be lost by the adoption of hard-line adversarial positions by any of the parties with a vested interest in the outcome. We should learn from the experience in Canada, New Zealand and the United States where successful accommodations have been reached. The processes adopted in those countries can be adapted for adoption here. Experience has shown that a process of consultation, mediation and reconciliation of land claims based upon mutual respect is essential and as important as the ultimate outcome.

It is often argued that making special provision for Indigenous people, as by providing an Aboriginal legal service or funding such a service, infringes the principle of equality before the law and is discriminatory. Experience in the United States and Canada suggests that the principle of equality before the law is consistent with special treatment of Indigenous peoples, for whom there is a specific constitutional responsibility. The Canadian Parliament, in the exercise of its power with respect to Indians can validly enact special laws based upon a 'legitimate legislative purpose in the light ... of long and uninterrupted history' or on 'Indian customs and values' provided that they do not exclude Indians from the enjoyment of basic rights and freedoms. ${ }^{64}$ In the United States, federal legislation dealing specifically with Indians is consistent with the guarantee of equal protection before the law if there is a rational basis 'for the legislative classification in the light of its legitimate purpose'. As in Canada, the United States courts have been strongly influenced by the special federal responsibility for Indians under the Constitution. ${ }^{65}$

\footnotetext{
${ }^{62}$ Local and Regional Agreements 1997. $\quad{ }^{64}$ Attorney-General of Canada v Canard (1975) 52 DLR 3d 548: 575; and see Slattery 1987.

${ }^{63}$ Ah Kit 2002.

${ }^{66}$ Supreme Court of Alberta 1991.
} 
What needs to be recognised is that treating unequals equally can infringe the principle of equality before the law as much as by treating equals unequally. In this respect I note that the Report of the Task Force on the Criminal Justice System and its Impact on the Indian and Metis People of Alberta ${ }^{66}$ published in April 1991 under the Chairmanship of the Hon Mr Justice Robert Cawsey of the Supreme Court of Alberta, commences with a quotation from The Sacred Tree, namely:

The final lesson ... is the lesson of balance, for wisdom teaches how all things fit together. And balance, when applied to the interconnectness of all human beings, becomes justice. With its aid, the traveller can see all things as they really are. Without it, there can be no peace or security in the affairs of the world.

\section{References}

\section{Books, articles and reports}

Ah Kit, J 2002, Ministerial Statement, Northern Territory Parliament, 7 March 2002, http://www.nt.gov. au/ocm/speeches/20020305_ahkit_aboriginal. shtml, 8 March 2002.

Australian Bureau of Statistics 2002, 2015.0 Census of Population and Housing: Selected Social and Housing Characteristics, Australia, AGPS, Canberra, available at http://www.abs.gov.au/ ausstats/abs@nsf, viewed 17 June 2002.

Australian Institute of Aboriginal and Torres Strait Islander Studies, available at http://www.aiatsis. gov.au/lbry/dig_prgm/treaty/atc.htm

Australians for Native Title and Reconciliation 2002 Why 'practical reconciliation' is bad policy, available at http://www.antar.org.au/prac_rec. html, viewed 23 June 2002.

Berndt, Ronald M and Catherine $\mathrm{H}$ 1999, The World of the First Australians [1964], 5th edn, Aboriginal Studies Press, Canberra.

Clark, G 2000, A long journey into daylight for all Australians, Sydney Morning Herald, 8 May, http://old.smh.com.au/news/specials/local/ corroboree/corro21.html, viewed 23 June 2002.

Cockayne, J 2001, 'More Than Sorry: Constructing a Legal Architecture for Practical Reconciliation', Sydney Law Review 23(4): 577.
Council for Aboriginal Reconciliation (CAR) 2000, Documents of Reconciliation, Corroboree 2000 Sydney, available at http://www.austlii.edu. $\mathrm{au} / \mathrm{au} /$ orgs/car/docrec/policy/brief/terran.htm, viewed 18 June 2002 .

Deane, Sir William 2001, On the Occasion of the Conferral of the Degree of Doctor of Laws Honoris Causa and the Delivery of the Occasional Address - University of New South Wales, Sydney, available at http://www.gg.gov.au/textonly/ speeches/2001/010518.html, viewed 18 June 2002.

Dodson, P 1997, Reconciliation and the Law Learning Together Workshop, Australians For Aboriginal Reconciliation in association with the Supreme Court of Western Australia and the Law Society of Western Australia, 21 February.

Fraser M 2000, The 5th Vincent Lingiari Memorial Lecture, 24 August, available at http:// www.austlii.edu.au/au/orgs/car/media/ 240800 Lingiari.htm, viewed 18 June 2002.

Hagen, R 2001, 2001 - Time for a Treaty? Some reflections, August 2001, http://www. netspace.net.au/ rodhagen/2001the\%20state\%200f\%2oplay.html, viewed 22 June 2002. 
Hawke, R 1988, 'A Time for Reconciliation', in K Baker (ed) $A$ Treaty With the Aborigines?, Institute of Public Affairs, Canberra.

Indigenous Law Resources, Reconciliation and Social Justices Library 2002, Walking Together The First Steps, available at http://www.austlii.edu.au/au/ other/IndigLRes/car/1994/1/140.html, viewed 20 June 2002.

Lane, PH 1999, 'Nationhood and Sovereignty in Australia,' The Australian Law Journal, 73(2).

Langton, M, ‘A Treaty Between Our Nations?' Inaugural Professorial Lecture, University of Melbourne, available at http://www.Indigenous.unimelb.edu. au/lecture3.html, viewed 18 June 2002.

Local and Regional Agreements, available at http:// www.austlii.edu.au/au/other/IndigLRes/ car/1997/3/book4?pages/041rao2.htm, viewed 22 June 2002.

Nyungah Circle of Elders, Joint Press Release, 17 June 2001, available at http://www.nyungah.org. $\mathrm{au} /$ statements/swanbourne.html, viewed 22 June 2002.

Oxfam, Community Aid Abroad 2000, 'Reconciliation - Where to from here? The Case for a Treaty, Polliewatch, no 42, available at http://www.caa. org.au/campaigns/polliewatch/reconciliation. html, viewed 23 June 2002.

Ruddock, P 2002, 'Native title works, but land alone won't fix Indigenous problems', Age, 14 June.

Slattery, B 1987, 'Understanding Aboriginal Rights', Canadian Bar Review 66(4).

Strelein, L 2000, 'Dealing with 'Unfinished Business': A Treaty for Australia', Public Law Review 11(4).

Supreme Court of Alberta 1991, Justice on Trial (Cawsey Report): Report of the Task Force on the Criminal Justice System and its Impact on the Indian and Metis People of Alberta, vol 1, Main Report, March.

Tickner R 1991, Aboriginal Reconciliation A Discussion Paper, available at http://www.churchandnation. pcnsw.org.au/C\%20\&\%20N\%201991.pdf

United Nations 1999, Study on Treaties, Agreements and Other Constructive Agreements Between States and Indigenous Populations: Final Report, United Nations, Geneva.

\section{Legislation}

Native Title Act 1993 (Cth).

\section{Case Law}

Attorney-General of Canada v Canard (1975) 52 DLR 3d 548 at 575 .

Morton v Mancari 417 US 535 (1974).

Miliipum v Nabalco Pty Ltd (1971) 17 FLR 141. 